lawyer raising this point, and any technical judge giving a similar ruling that would prevent the physician defendant testifying in his own behalf, in a suit for damages arising from death of a party from alleged malpractice on part of defendant physician.

There is another gratifying thing about the ending of this case in the fact that the profession had influence enough with our law makers to have them make the needed change.

$$
\text { Respectfully, W. H. SharP, M.D. }
$$

\section{The Insidious Advertisement.}

Philadelphia, March 20, 1897.

To the Editor:-Probably no one knows better than a med. ical editor that eternal vigilance is the price of other things beside liberty; and nowhere is vigilance more essential than in guarding against the schemes of the manufacturer of proprietary preparations. The Jounnal, with its settled and wel understood policy of refusing reading notices, offers an attractive field in which to spread advertisements disguised as regular scientific communications.

Many of the weekly medical journals of the Eastern cities and Europe, lend their aid to such schemes, some of them, perhaps, by inadvertence, others apparently with full intention. But this will not justify the Journal of the American MEDICal Association in lowering its standard of requirements in the least. It is perhaps impossible to judge when the eulogy of a special preparation is entirely sincere on the part of a writer, whose judgment and originality may be unequal to his ambition to write; and when it is pure fake, gotten up for a fixed price, or in the hope that the wide circulation the manufacturer will give to reprints will prove a step toward fame (?) or fortune to the writer. But it really is not necessary to go into this question of motives. When an article shows marked enthusiasm for a new drug, the extended use of which will benefit a particular manufacturer, it must be regarded with suspicion, and if in other respects it seems of little importance the safe rule is to return it with thanks-thanks for the fact that we have not been caught by it.

It has seemed to me that in two or three recent instances good opportunities for indulging in such thankfulness have been missed, and that articles have appeared in the Journal that are liable to bring a crop of such concealed reading notices regarding other patented or proprietary preparations. Of course it is very hard to refuse some member of the Associa. TION, who thinks he has discovered a good thing and wants it published in the JourNaL, not recognizing that the source of his discovery was the plausible talk of the glib agent who left him the sample. This being the case, the members of the Association ought to make it as easy for you as possible to refuse such communications, by calling attention to them and expressing the general feeling through the columns of the JouRnal. Even the vigilance of the editor will relax, or prove insufficient unless it is actively supported by the sentiment of the Association. Therefore I write to express to you my opinion of the articles in question, which need not be further advertised here, but which are named on the accompanying slip, and to ask others who notice what seem to be delinquencies of the sort, to pursue a similar course, and not to allow the unity and influence of the Association to be undermined by secret criticism and dissatisfaction.

$$
\text { Cordially yours, EDWARD JACKson, M.D. }
$$

The Physio-Medical School?

North EAst, PA., March 15, 1897.

To the Editor:-Can you give through the columns of your valuable JournaL a short history of what is known hereabouts as the physio-medical school of the practice of medicine. I would like to know something as to its origin, wherein it differs from the Regular, how many colleges it has, and as to what States recognize it as a separate school, and especially as to whether any State law names a physio-medical practitioner as one of the legal examiners for that school upon any State Medical Examining Board?

This may seem to be a long string of wants, but I am anxious to have it answered, as I see you are in the business of exposing humbugs.

The following is my reason for asking you for the above information. We have near here a physio-medical practitioner who has never been before our State Board, and is not registered. He has been cited before the Board, but refuses to go on the ground that there is no one on the Board of his par ticular school to examine him. The State Board notified him to cease his illegal practicing, but so far he has taken no notice of their warning. Our society has now taken the matter in hand and has him under bonds for court. He proposes to fight on the ground that his school is not recognized by the State, and hence he is not answerable to its law. He claims to have been before the Illinois Board and to be registered in Cook County. Hence my question: Has the Illinois Board a physio-medical man as one of its members, and is that school thus recognized by the State law? By giving a short history in the Journal you will greatly oblige a subscriber.

$$
\text { B. H. Putnam, M.D. }
$$

\section{A Revival of the Kansas Case.}

Milwaukee, Wis., March 22, 1897.

To the Editor:-In your issue of the 20th inst., you speak of the "Kansas Hypnotism Case" and say that it was "one of the first in which the plea of hypnotic influence had been employed by the prosecution in the criminal courts." In the Journal for June 8, 1895 (p. 903) you published a letter written by me in which the points discussed in the supreme court of Kansas were quoted and the law journal in which the case first appeared was named. It was then shown that the supreme court had nowhere, in its summing up of the testimony, mentioned the subject of hypnotism. Soon after the publication of this letter, some magazine, which I can not now recall, pub. lished an interview with the trial judge of the case; and he rather emphatically denounced the story that the plea of hypnotism was entertained by his court, and said that it was the work of a sentimental reporter. The only basis for the story was the fact that McDonald's lawyer in speaking of the influence that Gray held over him (McDonald) said: "This influence was so great that one might almost say it was hypnotic.' J. M. MADDEN, M.D.

\section{Muscular Dystrophy.}

Philadelphia, March 15, 1897.

To the Editor:-I am desirous of learning of the occurrence of muscular dystrophies, including pseudo-hypertrophic paralysis, idiopathic muscular atrophy, Erb's juvenile (scapulo-humeral) atrophy and facio-scapulo-humeral (jnfantile) atrophy of Landouzy-Dejerine, in colored persons and especially in those of pure, unmixed African parentage. I shall be grateful to receive information from any one who has encountered or has knowledge of cases of this nature. Respectfully,

224 South Sixteenth St. Augustus A. Eshner, M.D.

\section{The Journal Train.}

Purceld, Ind., March 20, 1897.

To the Editor:-Will you kindly state in next Journal the exact date the Journal Train will leave Chicago, over what road, the rate for round trip from there, time limit at Philadelphia, and must passage be engaged in advance for that train. Very respectfully, Milton McMurtry, M.D.

Answer: 'The Journal Special Train will leave by the Penn- 